\title{
Analisis Lingkungan Kewirausahaan: Studi Kasus Pada Siswa Kelas XII SMK
}

\author{
R.A. Tammie ${ }^{1}$, B.L. Nuryanti \& D.H. Utama \\ Universitas Pendidikan Indonesia \\ riekeamaluthviet@gmail.com
}

\begin{abstract}
This study aims to determine the analysis of entrepreneurial environment and entrepreneurial motivastion at student grade XII in SMK Negeri 1 Cimahi. This research uses descriptive approach with explanatory survey method. The student analysis unit is 167 people. Data collection using questionnaire. The analysis technique used is descriptive technique by using frequency distribution. The result showed that entrepreneurial environment is in average category and entrepreneurial motivation is in average category. The differences in this study located on an object research, time research, a measuring instrument, literature that used, the theory that is used and the results of the study.
\end{abstract}

\footnotetext{
ABSTRAK

Penelitian ini bertujuan untuk mengetahui gambaran lingkungan kewirausahaan dan motivasi berwirausaha siswa kelas XII SMK Negeri 1 Cimahi. Penelitian ini menggunakan pendekatan deskriptif dengan metode explanatory survey. Unit analisis siswa sebanyak 167 orang. Pengumpulan data dengan menggunakan kuesioner. Teknik analisis yang digunakan adalah teknik deskriptif dengan menggunakan distribusi frekuensi. Hasil penelitian menunjukan lingkungan kewirausahaan berada pada kategori sedang dan motivasi berwirausaha berada dikatagori sedang. Perbedaan dalam penelitian ini terletak pada objek penelitian, waktu penelitian, alat ukur, literatur yang digunakan, teori yang digunakan dan hasil penelitian.
}

\author{
ARTICLE INFO: \\ Article history: \\ Received 15 June 2018 \\ Revised 15 June 2018 \\ Accepted 16 June 2018 \\ Available online 5 September \\ 2018
}

Keywords:

Entrepreneurial

environtment,

Entrepreneurial

motivation

\section{Kata kunci:}

Lingkungan kewirausahaan, Motivasi berwirausaha.

\section{PENDAHULUAN}

Pemerintah Indonesia telah sejak lama menjadikan pendidikan kewirausahaan sebagai salah satu pilar ekonomi dalam menghadapi perubahan ekonomi dan sosial. Tingginya angka wirausaha tentu didorong oleh tingginya motivasi seseorang dalam berwirausaha. Motivasi berwirausaha merupakan salah satu kunci determinasi keberhasilan usaha (Eijdenberg, 2016). Fokus Motivasi berwirausaha tertuju pada pengambilan resiko dan ketertarikan untuk mencapai keberhasilan usaha (Ismail, Husin, Abdul, Hanum, \& Che, 2016). Penelitian di berbagai bidang telah menunjukan apa motivasi seseorang untuk memulai berwirausaha (Knight, 2015). Penelitian tentang motivasi berwirausaha penting untuk diteliti untuk mengetahui motivasi dan perilaku membantu memahami bagaimana mereka melaksanakan kegiatan sehari-hari dan sesuai dengan lingkungan, serta memahami bagaimana mereka memprediksi kemajuan 
bisnis berskala kecil mikro dan menengah (Eijdenberg, 2016).

Rendahnya motivasi berwirausaha merupakan salah satu permasalahan dalam kewirausahaan. Permasalahan motivasi berwirausaha jika diabaikan akan menyebabkan semakin berkurangnya jumlah wirausaha disuatu negara (Dehkordi, Sasani, Candidate, \& Management, 2012). Mengembangkan perilaku kewirausahaan diperlukan proses yang mencakup identifikasi sifat-sifat yang berhubungan dengan kewirausahaan (Mulyadi \& Irawan, 2016). Semakin rendah motivasi seorang siswa SMK untuk berwirausaha, maka semakin rendah wirausaha yang terbentuk setelah siswa menyelesaikan jenjang pendidikannya. Hal ini tentu dipengaruhi bagaimana proses belajar mengajar disekolah. Berbagai metode pembelajaran telah dikembangkan guna meningkatkan hasil belajar peserta didik, baik berupa perubahan sikap, bertambahnya ilmu, dll (Fayolle, Boluk \& Mottiar, Sastradinata, Yao).

Penelitian tentang tingkat motivasi berwirausaha telah dilakukan oleh banyak peneliti. Permasalahan tingkat motivasi berwirausaha menjadi penelitian baik di dalam bidang pendidikan maupun ilmu praktis (Boluk \& Mottiar, 2014). Memahamai faktor perilaku yang mendukung motivasi berwirausaha dan memfasilitasi siswa dalam berwirausaha berpengaruh dalam mendorong siswa untuk berwirausaha (Dehkordi et al., 2012). Penelitian menunjukan pembelajaran kewirausahaan tidak menunjukan peningkatan motivasi siswa dalam berwirausaha. Mengingat beberapa penelitian mengatakan siswa yang mengikuti pelatihan yang didalamnya terdapat kurikulum kewirausahaan menunujukan kecenderungan dan motivasi untuk berwirausaha (Sarmento, 2016). Pendidikan dan Latihan berpengaruh terhadap sikap dan perilaku kewiraushaaan mahasiswa di lingkungan pendidikan (Mulyadi, 2010)
Membangun motivasi berwirausaha pada siswa dapat dilakukan melalui kegiatan akademik maupun non akademik ( Orziemgbe et al., 2014). Contoh kegiatan akademik adalah pembelajaran kewirausahaan dapat mendorong siswa untuk lebih termotivasi untuk berwirausaha. Melalui pengembangan lingkungan kewirausahaan sekolah akan mampu menciptakan motivasi berwirausaha yang lahir dari diri siswa sehingga terbentuk motivasi yang lebih kuat dari pada motivasi yang terbentuk karna lingkungan atau faktor eksternal.

Peningkatan lingkungan kewirausahaan yang kondusif menjadi solusi yang efektif dalam meningktakan motivasi berwirausaha (Shetzer, Stackman, \& Moore, 2010). Penelitian yang dilakukan oleh Olvecka (2013) menyatakan bahwa lingkungan kewirausahaan berpengaruh positif dan signifikan terhadap motivasi berwirausaha, sedangkan penelitian yang dilakukan oleh Fereidouni, Masron, \& Nikbin (2010) menyatakan bahwa lingkungan kewirausahan kurang berpengaruh signifikan terhadap motivasi berwirausaha siswa.

Teori yang dikemukakan oleh Nafziger (2011) bahwa business environment mempengaruhi motivasi berwirausaha. Lingkungan kewirausahaan berpengaruh pada perilaku dan karakteristik wirausaha seseorang. Berdasarkan teori tersebut maka faktor lingkungan kewirausahaan berpengaruh pada motivasi berwirausaha siswa. Siswa SMK yang memiliki lingkungan kewirausahaan yang kondusif cenderung akan lebih termotivasi untuk berwirausaha.

Berdasarkan latar belakang masalah di atas, maka tujuan penelitian ini adalah untuk memperoleh hasil temuan mengenai: (1) gambaran lingkungan kewirausahaan dan (2) motivasi berwirausaha.

\section{KAJIAN PUSTAKA}

Lingkungan kewirausahaan merupakan kombinasi dari beberapa faktor yang memainkan peran dalam membangun 
kewirausahaan (Fereidouni et al., 2010) Lingkungan kewirausahaan merupakan gabungan dari beberapa faktor yang menyebabkan terjadinya proses kewirausahaan yang dapat membentuk wirausaha (Koranti, 2013)

Keinginan untuk penciptaan kekayaan merupakan pendorong yang signifikan. Faktor ini diasumsikan tergantung pada lingkungan yang diberikan. Misalnya. Pajak pendapatan kewiraswastaan, keuntungan modal dan dividen bervariasi di berbagai lingkungan, negara bagian dan negara. Oleh karena itu ekspektasi finansial juga bisa dikaitkan dengan atribut lingkungan.Kemunculan peluang dan pengakuan telah ditemukan sebagai fenomena sentral dalam bidang kewirausahaan. Kemunculan peluang dan persepsi peluang masing-masing dapat dikaitkan dengan lingkungan (Gnyawali \& Fogel, 2010) dan diasumsikan berbeda dari lingkungan ke lingkungan lainnya.

Lingkungan kewirausahaan terbagi menjadi 3 dimensi yaitu dimensi linkungan sosial, methods dan lingkungan kebijakan (Mitra, 2013). Programmes merupakan lingkungan yang dapat mempengaruhi seseoarang melalui jaringan interpersonal dan sosial budaya . Programmes meliputi orangtua, teman sekolah dan masyarakat. Programmes mendukung kepercayaan seseoranguntuk berwirausaha.

Methods merupakan situasi pembangunan dan kompetisi pasar yang ada. Lingkungan kebijakan maksudnya adalah kebijakan dan peraturan pemerintah seperti hukum dan undang-undang yang mendukung seseorang untuk berwirausaha. Pada penelitian ini kebijakan yang dimaksud adalah kebijakan sekolah dan orangtua dalam mendukung proses kewirausahaan siswa. Siswa yang memprolah dukungan dari sekolah dan orangtua akan merasa aman dan nyaman untuk berwirausaha.

Motivasi adalah kekuatan tersembunyi di dalam diri kita yang mendorong kita untuk berkelakuanj dan bertindak dengan cara yang khas (Basrowi, 2011). Motivasi merupakan proses psikologi yang mencerminkan interaksi sikap, kebutuhan, persepsi, dan keputusan yang terjadi pada diri seseorang Wahjosumidjo dalam Rusdiana (2014:70).

1. Dibawah ini beberapa motivasi berwirausaha menurut Djati Utomo (2007:31) Hasrat berprestasi (Need for Achievement/Nach). Seseorang yang kuat hasrat berprestasi tampakmya berpeluang besar untuk menjadu wirausaha sukses. Keinginan untuk mengerjakan sesuatu dengan lebih baik dimasa depan dibandingkan masa lalu

2. Kemandirian, kesaling tergantungan dan nasib baik. Salah satu aspek kompetensi yang penting bagi seorang wirausaha ialah kemampuan untuk mewujudkan sesuatu. Seseorang dengan keyakinan kendali nternal (internal control), percaya bahwa sebagian besar kehidupan dan bisnisnya dikendalikan oleh dirinya sendiri. Dengan keyakinan besar bahwa hal-hal penting ada dibawah kontrolnya, seorang wirausaha wajib tahu kapan dan dengan siapa ia harus menerima dan membagi Introl dalam hal-hal tertentu dengan pihak lain. Wirausaha mempercayai keberuntungan, peluang dan kesempatan.

3. Berani mengambil resiko. Secara umum wirausaha dapat menerima resiko yang timbul, dan ini cukup memadai dibandingkan hasil yang mereka kejar. Para wirausaha mengelola resiko antara lain melalui psikologis, misalnya menganggap ancaman halangan sebagai tantangan atau masalah peluang atau membicarakan bisnis dari sisi positifnya karena membicaraan sisi negative dapat melemahkan motivasi.

4. Pengalaman masa kecil. Kesulitan yang pernah mendera telah membuat banyak anak berikir kreatif dan inovatif untuk mengakali hidup. 
5. Frustasi dengan karir organisasi. Sebagian besar banyak merasakan karirnya terhenti di posisi tertentu atau mengalami ketidakpastian kerja. Bagi orang-orang tertentu situasi ini tidak membuat mereka terhenti tetapi memberi motivasi untuk tetap berkarya dengan berwirausaha.

6. Panutan. Banyak wirausaha yang termotivasi berwirausaha karena melihat keberhasilan orang, idola atau panutan mereka misalnya orang lain, keluarha terdekat, tetangga atau tokoh bisnis yang berhasil.

Motivasi merupakan salah satu faktor keberhasilan wirausaha dalam menyelesaikan tugasnya. Semakin besar motivasi maka semakin besar kesuksesan yang dicapai. Faktor-faktor pendorong disebut juga faktor penyebab kepuasan. Adanya kepuasan akan menambah semangat untuk melaksanakan aktivitas (Herzberg dalam Rusdiana 2014:71).

Menurut Hoy dan Cecil dalam Rusdiana (2014:71) , motivasi utama manusia untuk melakukan kegiatan adalah harapan. Tiga faktor yang menentukan motivasi, yaitu :

1. Harapan, yaitu keinginan bahwa suatu usaha yang dilakukan pasti akan berhasil.

2. Valensi, yaitu tingkat ikatan, keikutsertaan batiniah seseorang terhadap suatu aktivitas.

3. Peralatan/kebutuhan, yaitu pendukung, alat, kemampuan yang dimiliki seseorang guna mencapai tujuan.

Menurut Basrowi (2011: 67-68), motivasi seseorang menjadi wirausaha, yaitu:

1. Laba. Seorang wirausaha dapat menetukan berapa laba yang dkehendaki dan keuntungan yang akan diperoleh serta berapa yang akan dibayarkan kepada pihak lain dan karyawannya.

2. Kebebasan. Bebas mengatur waktu, bebas dari aturan yang menekan dan bebas dari aturan budaya organisasi.

3. Impian personal. Bebas mencapai standar hidup yang diinginkan, bebas dari rutinitas kerja yang membosankan. Imbalan untuk menentukan misi, visi dan impian sendiri.

4. Kemandirian. Memiliki rasa bangga, karena dapat mandiri dalam segala hal dengan usaha sendiri.

Menurut Jay Mitra (2012), secara umum motivasi berwirausaha dibagi menjadi beberapa dimensi yaitu :

1. Independence, adalah kemandirian. Seorang wirausaha ingin bisa membuat keputusan oleh dirinya sendiri. Seorang wirausaha tidak ingin bergantung dengan orang lain.

2. Self-Confidence, artinya percaya diri dibagi menjadi dua jenis yaitu percaya diri secara umum dan percaya diri secara khusus. Percaya diri secara umum yaitu seseorang yang percaya bahwa dirinya bisa menghadapi dunia, menghadapi tantangan, mengatasi hambatam dan percaya mampu mencapai impiannya. Sementara percaya diri khusus adalah kepercayaan dalam diri bahwa dirinya mampu mengatasi masalah secara khusus.

3. Achievement Motivation, maksudnya adalah motivasi berprestasi yaitu keinginan untuk mencapai prestasi standar yang cemerlang, misalnya untuk meningkatkan laba penghasilan, performa usaha, dll.

4. Drive to Action, yaitu arah untuk bertindak, seorang yang memiliki motivasi akan memiliki proactivity, ambisi, dan energi.

5. Egoistic Passion, yang dimaksud adalah egois dalam berwirausaha, yaitu keinginan untuk menang, berkuasa dan maju secara pribadi dalam berwirausaha.

6. Tenacity, artinya adalah keuletan, seorang yang memiliki motivasi berwirausaha akan cenderung ulet dalam bekerja dan berwirausaha. 
Berdasarkan uraian beberapa ahli diatas maka pada penelitian ini peneliti mengambil dimensi motivasi berwirausaha menurut Fayolle (2017) yaitu . Independence, SelfConfidence, Achievement Motivation, Drive to Action, Egoistic Passion dan Tenacity.

Berdasarkan penjelasan mengenai gambaran Lingkungan kewirausahaan dan motivasi berwirausaha, maka disusun sebuah paradigma analisis lingkungan kewirausahaan dan motivasi berwirausaha secara jelas digambarkan dalam Gambar 1 sebagai berikut:

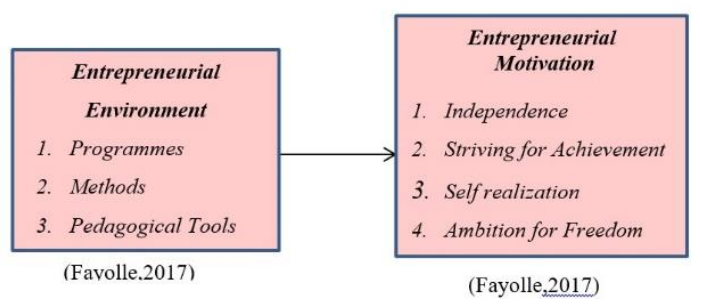

Gambar 1. Paradigma Penelitian

\section{METODE PENELITIAN}

Metode penelitian yang digunakan dalam penelitian ini adalah penelitian deskriptif dan verifikatif. Penelitian deskriptif dilakukan untuk mengetahui dan menjadi mampu untuk menjelaskan karakteristik variabel yang diteliti dalam suatu situasi (Sekaran, 2014). Penelitian deskriptif mencoba menggambarkan atau memahami karakteristik atau profil dari suatu variabel penelitian. Studi deskriptif yang menampilkan data dalam bentuk yang bermakna, dengan demikian membantu untuk (1) memahami karakteristik sebuah kelompok dalam situasi tertentu, (2) memikirkan secara sistematis mengenai berbagai aspek dalam situasi tertentu, (3) memberikan gagasan untuk penyelidikan dan peneitian lebih lanjut, dan (4) membuat keputusan tertentu yang sederhana (seperti berapa banyak dan jenis orang seperti apa yang sebaiknya ditransfer dari satu departemen ke lainnya) (Sekaran, 2014).
Berdasarkan jenis penelitian yaitu penelitian deskriptif maka metode yang digunakan dalam penelitian ini adalah explanatory survey yang bertujuan untuk mengetahui hubungan antar variabel dengan cara pengujian hipotesis. Metode explanatory survey adalah penelitian yang dilakukan untuk mengetahui sesuatu secara keseluruhan dari wilayah atau objek penelitian (Nasahudin 2012:56). Kesimpulan dari hasil penelitian tersebut berlaku umum (general) untuk seluruh informasi dari sebagian populasi dikumpulkan langsung ke tempat kejadian secara empirik dengan tujuan untuk mengetahui pendapat dari sebagian populasi terhadap objek yang diteliti

Sumber data penelitian adalah sumber data yang diperlukan untuk penelitian baik yang diperoleh secara langsung kepada pengumpul data (data primer, maupun tidak langsung kepada pengumpul data) atau melalui orang lain/dokumen (data sekunder yang berhubungan dengan objek penelitian (Sugiyono, 2017:129). Sumber data yang dimaksud dalam penelitian adalah subjek dari mana data tersebut diperoleh (Arikunto, 2010:129).

Populasi yaitu kumpulan dari individu dengan kualitas serta ciri-ciri yang telah ditetapkan. Populasi merupakan sejumlah objek yang akan dijadikan sumber penelitian (Yang, Ju, \& Lee, 2016). Populasi adalah wilayah generalisasi yang terdiri atas objek atau subjek yang mempunyai kuantitas dan karakteristik tertentu yang ditetapkan oleh peneliti untuk dipelajari dan kemudian ditarik kesimpulannya (Sugiyono, 2014:115). Populasi merupakan objek yang lengkap dan jelas yang ingin dipelajari sifat-sifatnya serta merupakan keseluruhan elemen atau anggota dari suatu wilayah yang menjadi sasaran penelitian atau merupakan keseluruhan dari objek penelitian (Waqas et al., 2014). Pengambilan sampel diperkenankan mengambil sebagian dari objek populasi yang telah ditentukan, dengan catatan bagian yang diambil tersebut mewakili yang lain yang tidak 
diteliti (Sugiyono, 2014:150). Teknik penarikan sampel yang digunakan dalam penelitian ini adalah teknik penelitian populasi atau sensus, karena sampel diambil dari seluruh populasi yang dinamakan sampel jenuh.

Penelitian ini menggunakan teknik simply random sampling karena jumlah populasi lebih dari 600 orang, dan sample yang diambil adalah yaitu sebanyak 167 orangsiswa. Populasi dalam penelitian ini adalah siswa kelas XII SMK Negeri 1 Cimahi yang berjumlah 676 orang. Teknik pengumpulan data yang digunakan adalah studi kepustakaan, studi lapangan dengan penyebaran kuesioner secara langsung, dan studi literatur. Teknik analisis data menggunakan distribusi frekuensi.

\section{HASIL DAN PEMBAHASAN}

Manurut Toutain et al.,(2017) perlua adanya usaha sadar dari sekolah untuk menciptakan dan membentuk kegiatankegiatan yang membuat siswa aktif dalam berkegiatan wirausaha. Fasilitas penunjang wirausaha, pelatihan kewirausahaan, dukungan sekolah, role model, serta perizinan usaha disekolah menciptakan lingkungan kewirausahaan yang mendorong siswa untuk berwirausaha (Alain Fayolle, 2008; Gnyawali \& Fogel, 1994; Yao, 2016).

Kemampuan pedagogik seorang guru ikut berperan dalam keberhasilan proses belajar mengajar di dalam maupun diluar kelas. Guru hendaknya menjadi panutan dan teladan serta pendorong siswa dalam proses pembelajaran kewirausahaan. Peningkatan kemampuan pedagogik guru melalui berbagai macam pelatihan sangat diperlukan untuk menunjang keberhasilan proses belajar mengajar (Purwanto, 2017; Syah, 2010)

Berdasarkan hasil pengolahan data yang dilakukan melalui penyebaran angket pada siswa kelas XII SMK Negeri 1 Cimahi, lingkungan kewirausahaan dapat diukur melalui perhitungan rata-rata dimensi dan perhitungan skor keseluruhan. Berikut ini dipaparkan hasil dari rekapitulasi perhitungan skor:

Tabel 1. Rekapitulasi Dimensi Lingkungan Kewirausahaan

\begin{tabular}{lllll}
\hline No & Dimensi & $\begin{array}{l}\text { Total } \\
\text { skor }\end{array}$ & $\begin{array}{l}\text { Skor } \\
\text { ideal }\end{array}$ & $\mathbf{\%}$ \\
\hline 1 & Programmes & 13187 & 23380 & 56 \\
2 & Methods & 13586 & 23380 & 53 \\
3 & $\begin{array}{l}\text { Pedagogyc } \\
\text { Skill }\end{array}$ & 13457 & 23380 & 53 \\
\multicolumn{2}{l}{ Total } & 39230 & 70140 & 56 \\
\hline
\end{tabular}

Berdasarkan item pernyataan (indikator) menunjukkan bahwa nilai tertinggi berada pada dimensi methods dengan skor 13586 atau sebesar $58 \%$ yang atinya sebagian besar siswa berpendapat bahwa metode yang digunakan oleh guru dan sekolah dalam proses pembelajaran sudah baik. Manurut Toutain et al.,(2017) perluaadanya usaha sadar dari sekolah untuk menciptakan dan membentuk kegiatan-kegiatan yang membuat siswa aktif dalam berkegiatan wirausaha. Fasilitas penunjang wirausaha, pelatihan kewirausahaan, dukungan sekolah, role model, serta perizinan usaha disekolah menciptakan lingkungan kewirausahaan yang mendorong siswa untuk berwirausaha (Alain Fayolle, 2008; Gnyawali \& Fogel, 1994; Yao, 2016).

Sedangkan untuk dimensi dengan nilai terendah yaitu dimensi pedagogic skill dengan skor 12457 atau sebesar 53\%. yang artinya sebagian besar siswa berpendapat bahwa dimensi pedagogic skill pada lingkungan kewirausahaan disekolahnya kondusif. Guru berperan sebagai input atau masukan dalam proses belajar mengajar (Purwanto, 2017). Kemampuan pedagogik seorang guru ikut berperan dalam keberhasilan proses belajar mengajar di dalam maupun diluar kelas. Guru hendaknya menjadi panutan dan teladan serta pendorong siswa dalam proses pembelajaran kewirausahaan. Peningkatan kemampuan pedagogik guru melalui berbagai macam pelatihan sangat diperlukan untuk menunjang 
keberhasilan proses belajar mengajar (Purwanto, 2017; Syah, 2010)

Sedangkan dilihat dari garis kontinum yang telah dihitung

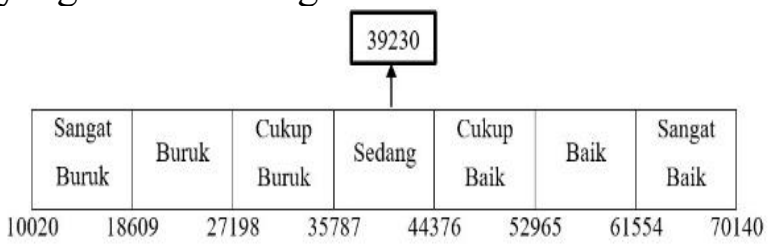

Sumber: Hasil Pengolahan Data, 2018

Gambar 2. Garis Kontinum Lingkungan Kewirausahaan

Secara keseluruhan varibael lingungan kewirausahaan memperoleh skor 39230 atau sebesar $56 \%$ yang artinya sebagian besar siswa merasa lingkungan kewirausahaan disekolahnnyaberada pada kategori sedang. Melalui pengembangan lingkungan kewirausahaan sekolah akan mampu menciptakan motivasi berwirausaha yang lahir dari diri siswa sehingga terbentuk motivasi yang lebih kuat dari pada motivasi yang terbentuk karna lingkungan atau faktor eksternal. Peningkatan lingkungan kewirausahaan menjadi solusi yang efektif dalam meningktakan motivasi berwirausaha (Nastase, 2012).

Salah satu aspek kompetensi yang penting bagi seorang wirausaha ialah kemampuan untuk mewujudkan sesuatu. Seseorang dengan keyakinan kendali nternal (internal control), percaya bahwa sebagian besar kehidupan dan bisnisnya dikendalikan oleh dirinya sendiri. Dengan keyakinan besar bahwa hal-hal penting ada dibawah kontrolnya, seorang wirausaha wajib tahu kapan dan dengan siapa ia harus menerima dan membagi lntrol dalam hal-hal tertentu dengan pihak lain (Utomo, 2007).

Seseorang yang kuat hasrat berprestasi tampakmya berpeluang besar untuk menjadu wirausaha sukses. Keinginan untuk mengerjakan sesuatu dengan lebih baik dimasa depan dibandingkan masa lalu (Utomo, 2007) Self realization ( realisasi diri ) yaitu bagaimana individu merealisasikan dirinya.
Realisasi diri tersebut bermakna bahwa individu akan selalu termotivasi apabila dirinya hidup dalam suatu cara yang sesuai dengan peran yang lebih disukai, diperlakukan sesuai dengan tingkatan yang lebih disukai dan dihargai sesuai dengan cara yang mencerminkan penghargaan seseorang terhadap kemampuannya (Pugacheva et al., 2016)

Bebas mengatur waktu, bebas dari aturan yang menekan dan bebas dari aturan budaya organisasi. Sekolah perlu mendukung siswa agar dapat hidup bebas namun sesuai dengan aturan yang berlaku, kebebasan dalam memilih cita-cita, kebebasan dalam menuangkan ide, kebebasan dalam berpendapat, dll. Namun, kebebasan tersebut masih perlu menjadi perhatian sekolah, misalnya dengan dibuat peraturan tata tertib disekolah yang bersifat tertib namun tidak mengekang siswa dalam mengembangkan dirinya (A Fayolle, Kyro, \& Liñán, 2015).

Berdasarkan hasil pengolahan data yang dilakukan melalui penyebaran angket pada siswa kelas XII SMK Negeri 1 Cimahi motivasi berwirausaha dapat diukur melalui perhitungan rata-rata dimensi dan perhitungan skor keseluruhan. Berikut ini dipaparkan hasil dari rekapitulasi perhitungan skor

Tabel 2. Rekapitulasi Dimensi Motivasi

Berwirausaha

\begin{tabular}{lllll}
\hline No & Dimensi & $\begin{array}{l}\text { Total } \\
\text { skor }\end{array}$ & $\begin{array}{l}\text { Skor } \\
\text { ideal }\end{array}$ & \% \\
\hline 1 & $\begin{array}{l}\text { Independence } \\
2\end{array}$ & 13187 & 23380 & 56 \\
& $\begin{array}{l}\text { Striving for } \\
\text { Achievement }\end{array}$ & 13586 & 23380 & 58 \\
& $\begin{array}{l}\text { Self } \\
\text { realization }\end{array}$ & 12457 & 23380 & 53 \\
4 & $\begin{array}{l}\text { Ambition for } \\
\text { Freedom }\end{array}$ & 12928 & 23380 & 55 \\
\hline Total & 52158 & 93520 & 56 \\
\hline
\end{tabular}

Berdasarkan item pernyataan (indikator) menunjukkan bahwa nilai tertinggi berada pada dimensi striving for achievement dengan skor 13586 atau sebesar 58\%. yang artinya sebagian besar siswa berpendapat bahwa striving for achievement atau kerja keras untuk 
prestasi pada siswa dalam motivasi berwirausaha cukup baik. Seseorang yang kuat hasrat berprestasi tampakmya berpeluang besar untuk menjadu wirausaha sukses. Keinginan untuk mengerjakan sesuatu dengan lebih baik dimasa depan dibandingkan masa lalu (Utomo, 2007).

Sedangkan untuk dimensi dengan nilai terendah yaitu dimensi self realization dengan skor 12457 atau sebesar 53\%. yang artinya sebagian besar siswa berpendapat bahwa self realization atau realisasi diri pada siswa dalam motivasi berwirausaha cukup baik. Self realization ( realisasi diri ) yaitu bagaimana individu merealisasikan dirinya. Realisasi diri tersebut bermakna bahwa individu akan selalu termotivasi apabila dirinya hidup dalam suatu cara yang sesuai dengan peran yang lebih disukai, diperlakukan sesuai dengan tingkatan yang lebih disukai dan dihargai sesuai dengan cara yang mencerminkan penghargaan seseorang terhadap kemampuannya (Pugacheva et al., 2016).. Sedangkan dilihat dari garis kontinum yang telah dihitung adalah

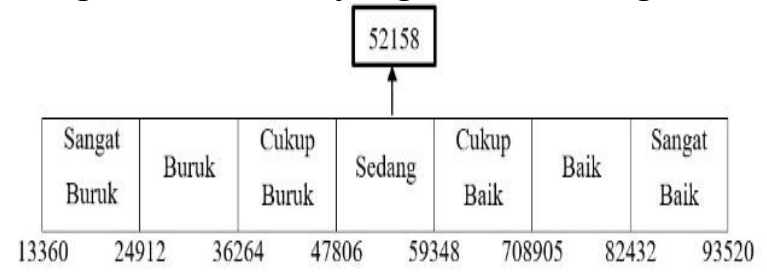

Gambar 3. Garis Kontinum Motivasi Berwirausaha

Gambar 3 mengemukakan bahwa secara ideal skor yang diharapkan untuk jawaban siswa kelas XII SMKN 1 Cimahi terhadap pertanyaan nomor 1 sampai dengan 60 adalah 93520. Secara keseluruhan varibael motivasi berwirausaha memperoleh skor 52158 atau sebesar 56\% yang artinya sebagian besar siswa merasa motivasi berwirausaha berada pada kategori sedang. Membangun motivasi berwirausaha siswa disekolah sangatlah penting. Melalui pengembangan lingkungan kewirausahaan sekolah akan mampu menciptakan motivasi berwirausaha yang lahir dari diri siswa sehingga terbentuk motivasi yang lebih kuat dari pada motivasi yang terbentuk karna lingkungan atau faktor eksternal. Peningkatan lingkungan kewirausahaan menjadi solusi yang efektif dalam meningktakan motivasi berwirausaha (Nastase, 2012).

\section{KESIMPULAN}

Berdasarkan hasil penelitian di pembahasan dikemukakan kesimpulan bahwa Gambaran mengenai lingkungan kewirausahaan bahwa sebagian besar siswa kelas XII SMK Negeri berpendapat bahwa lingkungan kewirausahaan siswa SMK Negeri 1 Cimahi berada pada kondisi sedang. Hal ini dapat dilihat dari indikator yang paling tinggi yaitu methods, diikuti indikator lainny yaitu programmes. Sedangkan indikator yang paling rendah yaitu pedagogic skill.

Gambaran mengenai motivasi berwirausaha pada sisw keals XII SMKN 1 CImahi sebagian besar berada pada kategori sedang . Hal ini dapat dilihat dari indikator yang memiliki skor paling tinggi yaitu striving for achievement dan diikuti indikator lainnya yaitu independence dan ambition for freedom. Sedangkan indikator yang paling rendah yaitu self realization.

Lingkungan kewirausahaan siswa kelas XII SMK Negeri 1 Cimahi sebagiam besar siswa berpendapat masuk dalam kategori sedang. Lingkungan kewirausahaan perlu diperbaiki dan ditingkatkan .Guru tentunya dituntut untuk dapat menggunakan metode pembelajaran yang menarik bagi siswa misalnya menggunakan model project based learning dan sebagainya. Begitupun dengan kurikulum yang sedang berlaku, siswa membutuhkan waktu untuk menyesuaikan diri dengan kurikulum yang berlaku (A Fayolle et al., 2015). Alangkah lebih baik jika guru dibekali pelatihan pelatihan disekolah dalam mengajar. Tidak hanya guru kewirausahaan , perlu dukungan dari semua guru untuk menyemangati dan memotivasi siswa untuk berwirausaha. Peran guru dalam menjadi 
contoh dan mendukung siswa sangatlah besar, karna guru merupakan panutan dan contoh bagi siswa (Toutain et al., 2017).

Motivasi berwirausaha siswa kelas XII SMK Negeri 1 Cimahi sebagiam besar siswa berpendapat masuk dalam kategori sedang. Motivasi berwirausaha perlu diperbaiki dan ditingkatkan Seseorang yang kuat hasrat berprestasi tampakmya berpeluang besar untuk menjadu wirausaha sukses. Keinginan untuk mengerjakan sesuatu dengan lebih baik dimasa depan dibandingkan masa lalu (Utomo, 2007).

\section{DAFTAR PUSTAKA}

Basrowi. (2011). kewirausahaan untuk Perguruan Tinggi. Bogor: Ghalia Indonesia.

Boluk, A. K., \& Mottiar, Z. (2014). Motivations of social entrepreneurs Blurring the social contribution and profits dichotomy, 10(1), 53-68. https://doi.org/10.1108/SEJ-01-20130001

Dehkordi, A. M., Sasani, A., Candidate, M. A., \& Management, E. (2012). Investigating the Effect of Emotional Intelligence and Personality Traits on Entrepreneurial Intention Using the Fuzzy DEMATEL Method University of Tehran, 3(13), 286296.

Eijdenberg, E. L. (2016). Does one size fit all? A look at entrepreneurial motivation and entrepreneurial orientation in the informal economy of Tanzania, 22(6), 804-934. https://doi.org/10.1108/IJEBR-12-20150295

Fayolle, A. (2008). Linking entrepreneurial orientation and dynamic capabilities: research issues and alternative models. The Dynamics between Entrepreneurship, Environment and Education, 308. https://doi.org/10.1017/CBO9781107415324 .004

Fayolle, A., Kyro, P., \& Liñán, F. (2015). Developing, shaping and growing entrepreneurship. Developing, Shaping and Growing Entrepreneurship. https://doi.org/10.4337/9781784713584

Fereidouni, H. G., Masron, T. A., \& Nikbin, D. (2010). CONSEQUENCES OF EXTERNAL ENVIRONMENT ON, 15(2), 175-196.
Gnyawali, D., \& Fogel, D. (1994). Environments for Entrepreneurship Development: Key Dimensions and Research Implications, (March). https://doi.org/1042258794184

Ismail, I., Husin, N., Abdul, N. M., Hanum, M., \& Che, R. (2016). Entrepreneurial Success among Single Mothers: The Role of Motivation and Passion. Procedia Economics and Finance, 37(16), 121-128. https://doi.org/10.1016/S22125671(16)30102-2

Kingdom, U., Orziemgbe, G., Chukwujioke, K., Aondoaver, T., \& Polytechnic, B. S. (2014). Relationship Between Emotional Intelligence And Entrepreneurial Performance: The Mediating, II(10), 1-16.

Knight, J. (2015). The evolving motivations of ethnic entrepreneurs. Enterprising Communities, 9(2), 114-131. https://doi.org/10.1108/JEC-10-2013-0031

Koranti, K. (2013). Analisis Pengaruh Faktor Eksternal Dan Internal, 5(1998), 8-9.

Mitra, J. (2013). Entrepreneurship, Innovation and Regional Development (1st ed.). New York: Routledge.

Mulyadi, H. (2010). Pengaruh Pendidikan dan Latihan Terhadap sikap kewirausahaan serta Implikasinya pada Perilaku kewiraushaaan Mahasiswa.

Mulyadi, H., \& Irawan, A. (2016). Pengaruh Keterampilan Wirausaha Terhadap Keberhasilan Usaha, 1(1), 213-223.

Nafziger, E. W. (2012). Economic Development (Fourth i). New York: Cambridge University Press.

Nastase, C. (2012). The Interactions Between Entrepreneurial, 12(2), 7-12.

Olvecka, V. (2013). Development Of Entrepreneurial Environment In Slovakia, 7(2), 216-229. https://doi.org/10.13165/IE13-7-2-06

Pugacheva, N. B., Ezhov, S. G., Kozhanov, I. V, Kozhanova, M. B., Ogorodnikova, S. V, Oshaev, A. G., ... Goloshumova, G. S. (2016). The Model of Self-realization Readiness Formation of Research Universities Students in the Process of Civic Education, 6(1), 128-133.

Purwanto, N. (2017). PSIKOLOGI PENDIDIKAN (28th ed.). Bandung: Remaja Rosdakarya. 
Rusdiana. (2014). Kewirausahaan Teori dan Praktek (1st ed., Vol. 52). Jakarta: Pustaka Setia. Retrieved from http://search.proquest.com/docview/1651837 258? accountid $=14548$

Sarmento, M. F. P. G. M. (2016). Predicting entrepreneurial motivation among university students: The role of entrepreneurship education, $58(7 / 8)$ https://doi.org/http://dx.doi.org/10.1108/ET01-2016-0019

Shetzer, L., Stackman, R. W., \& Moore, L. F. (2010). Business-Environment Attitudes and the New Environmental Paradigm, (March 2015), 37-41. https://doi.org/10.1080/00958964.1991.9943 057

Syah, M. (2010). Psikologi Pendidikan dengan pendekatan baru. Bandung: Remaja Rosdakarya.

Toutain, O., Fayolle, A., Pittaway, L., \& Politis, D. (2017). Role and impact of the environment on entrepreneurial learning. Entrepreneurship and Regional Development, 29(9-10), 869-888. https://doi.org/10.1080/08985626.2017.1376 517

Utomo, D. (2007). Menjadi Entrepreneur Jempolan. Jakarta: Replubika.

Yao, X. (2016). Effect of students 'perceived entrepreneurial environment, $8(1)$. https://doi.org/http://dx.doi.org/10.1108/JEE E-03-2015-0021 